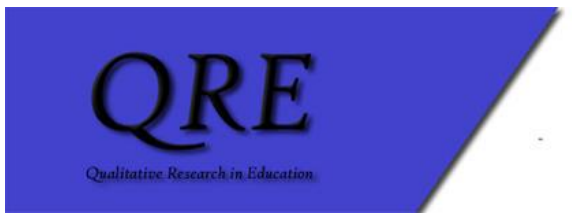

Hipatia Press

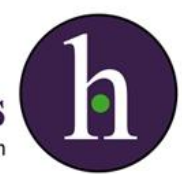

Instructions for authors, subscriptions and further details:

http://qre.hipatiapress.com

\title{
Stroking the Net Whale: a Constructivist Grounded Theory of Self-Regulated Learning in Virtual Social Spaces
}

Judita Kasperiuniene ${ }^{1,2}$, Vilma Zydziunaite ${ }^{3}$ \& Malin Eriksson ${ }^{4}$

1) Faculty of Informatics, Vytautas Magnus University, Lituania.

2) Centre for Cultural Communication and Education, Aleksandras Stulginskis University, Lituania.

3) Center for Quality and Innovations, Vytautas Magnus University, Lituania.

4) Department of Social Work, Umeå University, Sweden.

Date of publication: October $28^{\text {th }}, 2017$

Edition period: October 2017 - February 2018

To cite this article: Kasperiuniene, J., Zydziunaite, V., \& Eriksson, M. (2017). Stroking the net whale: a constructivist grounded theory of selfregulated learning in virtual social spaces. Qualitative Research in Education, 6(3), 276-302. doi:10.17583/qre.2017.2756

To link this article: $\mathrm{http}: / / d x . d o i . o r g / 10.17583 / q r e .2017 .2756$

\section{PLEASE SCROLL DOWN FOR ARTICLE}

The terms and conditions of use are related to the Open Journal System and to Creative Commons Attribution License (CC-BY). 


\section{Stroking the Net Whale: a}

\section{Constructivist Grounded Theory of Self-Regulated Learning in Virtual Social Spaces}

Judita Kasperiuniene

Vytautas Magnus University Aleksandras Stulginskis University

Malin Eriksson

Umeå University

(Received: 22 May 2017; Accepted: 25 September 2017; Published: 28 October 2017)

\section{Abstract}

This qualitative study explored the self-regulated learning (SRL) of teachers and their students in virtual social spaces. The processes of SRL were analyzed from 24 semi-structured individual interviews with professors, instructors and their students from five Lithuanian universities. A core category stroking the net whale showed the process of SRL skills development of university teachers and their students. This core category was constructed from three categories: building boats, angling in the multifaceted ocean, nurturing the big fish. Building boats showed social networking and identity marketing processes which are the same for both research participant groups. Angling in the multifaceted ocean implied personal capabilities and mutual trust dimensions, applicable to both teachers and students. Other dimensions of Angling in the multifaceted ocean differ: maintenance of liquid identities was observed for teachers; students stressed reinforcement of formal studies in virtual social spaces. Nurturing the big fish for both participant groups means academic communication; for university teachers, it also means professional knowledge development, and for students, virtual learning skills development. These findings contribute to understanding how the SRL of university teachers and their students progresses in virtual social spaces.

Keywords: constructivist grounded theory, self-regulated learning, university teachers, university students, virtual social spaces 


\section{Trazar la Red Ballena: una Teoría Fundamentada Constructivista del Aprendizaje Auto-Regulado en Espacios Sociales Virtuales}

Judita Kasperiuniene

Vytautas Magnus University Aleksandras Stulginskis University

Malin Eriksson

Umeå University
Vilma Zydziunaite

Vytautas Magnus University

(Recibido: 22 de mayo de 2017; Aceptado: 25 de septiembre de 2017; Publicado: 28 de octubre de 2017)

\section{Resumen}

Este estudio cualitativo exploró el aprendizaje autorregulado (AAR) de docentes y sus alumnos en espacios sociales virtuales. Los procesos de AAR se analizaron a partir de 24 entrevistas individuales semi-estructuradas con profesores y estudiantes de cinco universidades lituanas. Una categoría núcleo, trazar la red ballena, mostró el proceso de desarrollo de habilidades del AAR por parte de los profesores universitarios y sus estudiantes. Esta categoría se construyó a partir de tres subcategorías: (a) construcción de embarcaciones, que muestra redes sociales y procesos de marketing de identidad, los mismos para ambos grupos; (b) la pesca en el océano multifacético, que implica capacidades personales y dimensiones de confianza mutua, aplicables tanto a profesores como a estudiantes. Otras dimensiones de esta categoría difieren: para los profesores se observó el mantenimiento de las identidades líquidas, mientras que los estudiantes subrayaron el refuerzo de los estudios formales en espacios sociales virtuales y; (c) cultivar el pez grande, que significa comunicación académica para ambos grupos; para los profesores universitarios, también significa el desarrollo de conocimientos profesionales y para los estudiantes, el desarrollo de habilidades de aprendizaje virtual. Estos hallazgos contribuyen a comprender cómo el AAR de los profesores universitarios y sus estudiantes progresa en espacios sociales virtuales.

Palabras clave: teoría fundamentada constructivista, aprendizaje auto-regulado, profesor universitario, estudiante universitario, espacios sociales virtuales

2017 Hipatia Press

ISSN: 2014-6418

DOI: $10.17583 /$ qre.2017.2756 
A virtual social space is a network in which flux, open-ended, liquid and flowing learning occurs. Virtual social spaces were studied and Braidotti, 2013); psychologists (Csikszentmihalyi \& Wolfe, 2014); scholars in education (Griffith, Sawyer, \& Neale, 2003); new media and communication (Castells, 2013); science and technologies (Varnelis, 2012). Self-regulated learning (SRL) concerns application of general models of human (self) regulation to learning (Schunk \& Zimmerman, 2012). All the models of SRL share common assumptions: actors are treated as active builders of their personal learning processes; they construct meanings, goals and strategies from external and internal environments (Romero \& Lambropoulos, 2011); learners can monitor, control and regulate their learning behaviors (Karabenick \& Zusho, 2015); actors can set learning standards and motivate themselves to reach these goals (Littlejohn, Hood, Milligan, \& Mustain, 2016); self-regulatory activities are directly linked to achievement and performance (Pintrich, 2000). SRL processes that evolve in virtual social spaces transform human relationships: most of the time learners virtually communicate, exchange mediated experiences, share live moments everywhere, and crowdsource. Learners are challenged in developing SRL skills with permanent uncertainty, and in all forms of communication meltdown. Self-regulated learners continuously expand their fields of interests and make short-term commitments (Bauman, 2005).

Social media has the potential to bridge formal and informal learning through participatory digital academic cultures. The importance of blurring boundaries in formal and informal pedagogical practices increases, and formal and informal learning converge within the social media (Greenhow \& Lewin, 2016). Complex student-teacher relationships and interactions predict academic achievements (Crosnoe, Johnson, \& Elder, 2004). Student formal engagement increases because of the non-formal support provided by teachers (Pianta, Hamre, \& Allen, 2012). It is important that this type of support could be transmitted when both actors are positively positioned, motivated and self-regulated to receive, absorb and share knowledge.

In formal studies, students' and their teachers' communication is public. Informally, virtual contact is freely agreed and sought by both agencies. During formal lectures, active participants are known and teacher-learner roles are generally set in advance. On the other hand, informally, in virtual social spaces, academic agencies can remain anonymous and continuously 
change their roles (Eisenbeiss, Blechschmidt, Backhaus, \& Freund, 2012). Self-regulated learners constantly construct and de-construct their multiple identities within virtual social spaces, producing and consuming knowledge (Solomon, 2014) and developing virtual identity marketing strategies. Identity marketing is increasingly challenging in virtual social spaces where identity performances are seemingly untethered from the user's body that is sitting at the computer (Schultze, 2014). In their study on informal collaboration in groups, Griffith et al. (2003) found that development of creativity requires that actors develop feelings of mutual trust and empathy. In addition, the individual intentions should be in harmony with others in the group.

An observation of 70 university students' Facebook use made in Australia by Vivian, Barnes, Geer and Wood (2014) showed that many students leave their "academic journey traces" online and interact with their teachers. By this present study, we attempted to understand the processes of SRL of university students and their teachers taking place in virtual social spaces. We hold the position that SRL goes behind the walls of formal university teaching and learning and both main academic actors (university teachers and their students) in virtual social spaces become learners. We investigated the SRL of professors, instructors and their students meeting virtually after formal university classes in Facebook, LinkedIn or Research Gate virtual environments. The main research question was: how does the self-regulated learning of university students and their teachers develop in virtual social spaces?

\section{Methodology}

\section{Study Design}

The research was conducted in Lithuania amongst only Lithuanian academics. In total, 24 semi-structured interviews with 6 professors and associate professors, 6 instructors, 6 undergraduates, 6 graduate and $\mathrm{PhD}$ students from 5 Lithuanian universities were conducted to understand SRL in virtual social spaces.

A constructivist grounded theory method was applied in this study for gathering data, coding, sampling, sorting and theory constructing. This implied that; (i) the research process was treated as a social construction, 
letting new insights and additional questions emerge, observing and including them in a whole structure; (ii) methodological and analytical strategies of research were improvised and slightly changed if data showed it to be necessary; (iii) research decisions and descriptions were carefully studied and evaluated; (iv) tacit data meanings and silent processes were described and explained (Charmaz, 2008). After defining the research problem, research questions were chosen and a flexible interview plan created. Following data and constructed codes, the interview plan was adapted and additional questions formulated. Initial coding started after the first data collection. Data were analyzed comparatively with new data. Focus coding started after the first interview collection and initial coding. Constructing categories from data, codes and subcategories started after the focus coding of the first data. This process was iterative until the saturation of categories. Analytical memos were written, mapped and sorted during all the process of grounded theory construction. Later memos were integrated with the final grounded theory. Data collection procedures were implemented simultaneously with qualitative data analysis and concept generation (Charmaz, 2006).

\section{Sampling and Data Collection}

Professors and instructors were selected using snowball sampling. The first author chose the first participant who subjectively illuminated initial research interests for the interview. Later participants themselves proposed the new ones. Teachers were asked to recommend students from their virtual circle for further interviews. All interviews were held at university campuses over a period of two semesters during the academic year 2014/2015. The sample comprises 17 females and 7 males.

In-depth individual interviewing was chosen as the data collection method because of the research participants' inter-relations. University teachers are knowledge workers: they teach, share and express thoughts during formal lectures and other university activities. By the nature of their work, teachers are used to conversations and thus did not express any discomfort in being interviewed. Interviews help to learn of participants' experiences, to find out about their life situations and to explore their living worlds (Kvale, 2008). The interviews were actively evolving and the discussions spontaneously evoked additional questions. The shortest 
interview lasted 23 minutes and the longest took 1 hour and 42 minutes. The in-depth nature of individual interviews invoked the participant's online experiences. Interviews were recorded and later transcribed verbatim. Researchers conducted interviews in Lithuanian (informants' native language). Each interview consisted of two question parts: first, a description of the participant's activities and online friends; and, second, virtual communication experiences. Some examples of questions about virtual activities and friends were: "Tell me about your activities in a virtual space. How did they emerge? Have they changed over time? How have your personal actions evolved through these activities? Could you please describe the latest situation in which you learned, gained knowledge, received some benefits while networking in virtual social spaces? Do you follow/have friended persons, groups or institutions? Describe in more detail. How do you pick, chose, select persons, institutions, sites? Describe the process and its conditions in more detail." To explore virtual network activities, understand how people make sense of their situations in virtual social spaces and act on them, the researcher asked questions about virtual communication, for instance: "Tell me about the instructors, professors, students with whom you are online friends, who you follow. How and why did you become virtually connected? Could you please describe this virtual interaction? Please tell me the reasons why you invited them and/or accepted virtual requests/decided to follow? What is the value and meaning (for you) of online social communication with teachers and/or students? How have you personally contributed to the teachers, students and what do you gain while communicating online? What have you learned from online connection with your professors, students? What do you think they learned/achieved from a connection with you?" Following the interview plan, the questions to teachers and their students remained similar. Openended questions with focus on significant statements allowed different stories to emerge.

Interviews were conducted in the participants' natural environment university classes, professors' and instructors' rooms, auditoriums, public university halls and corridors. All the data collection and analysis were performed simultaneously. 


\section{Data Analysis}

Charmaz (2006) proposed a constructivist grounded theory coding or, in other words, defining what the data are about, in two main steps: initial and focused coding. The first step - initial coding - leads to close reading of interview texts, distinguishing various fragments of data and naming them. During the second step - focused coding - initial codes are selected, combined, compared and tested with other codes and extended data, integrated to larger amounts, synthesized and named again. Focused coding leads to theoretical coding and grounded theory construction (Charmaz, 2006). In our study, initial and focused coding started straight after gathering the first interview and was done incident by incident. This approach was chosen to extract the main idea or initial code from the event or proceeding. One incident was collected from a part of, or a few, logically related interview sentences. In vivo codes were used to characterize participants' social worlds and academic settings (Holton, 2007). Focused coding was done through comparing data to data, still keeping codes close to the data. This approach helped synthesizing and explaining larger data segments; going backwards and forward to new data. Coding helped to see the participant stories grounded in the data and lead to theoretical insights (Charmaz, 2011).

Extended theoretical graphical memos were drawn during all data collection and the analysis process to facilitate conceptualization of the data and to enable the open codes, sub-categories and categories to move upwards. Analytical maps (Clarke, 2005) analyzed data that were already collected. They showed the road to future data collection and pointed to the new interview participants (Birks, Chapman, \& Francis, 2008). They allowed constructing analytical notes, freezing the ongoing ideas, concepts and theoretical meanings. Finally, they provided a space required for new data collection. Graphical memos were done spontaneously after finishing each interview and contained everything that came to mind about codes, categories, interview participants, environments, and theoretical insights. Memo texts, maps and visuals helped to gain insights and explained already developed categories (Clarke, 2005). Clustering technique (a shorthand prewriting that gives a non-linear, visual, and flexible understanding and organization of materials) led to diagram relationships and situations. It 
provided a blueprint of how the data and topics fit together and how they were related to the phenomena (Charmaz, 2006).

\section{Ethics}

All the interview participants were informed about the purpose, methods and intended use of findings. The interviews were conducted with sensitivity, respecting the confidentiality of data. To ensure research confidentiality it was agreed with participants that names, places, schools, and subjects would not be announced. In accordance with international guidelines for research ethics (General Assembly of the World Medical Association, 2014), participants were introduced to the research topic in general. However, the interview questions were not revealed in advance. All students expressed their willingness to participate in a research. They responded: "being a student I am happy to contribute to quality of studies and science in general". There were teachers that refused to take part claiming they have "no time" or "were not active in virtual environments". Others asked for the interview questions in advance but these were not provided. All the participants were informed that data would be audiorecorded and later analyzed anonymously. Participants felt at ease only when provided official guarantees of anonymity. Potential threats arising from the research, such as psychological and emotional distress recalling specific learning situations; a decline of self-confidence; virtual reputation damage; and online relations were predicted and justified as low.

\section{Findings}

Teachers and their students are equally important actors in formal university teaching and learning processes. In non-formal and informal settings, many university students in Lithuania face the challenge of virtually communicating with the professors whom they know in real life, even if internet social spaces open the opportunities to communicate with or without showing your real identity. To better characterize the results of our grounded theory analysis, i.e. the SRL processes developing in virtual social spaces, we constructed categories using metaphors from the ocean and sea life. 
It was clear from our data that virtual social spaces are treated and experienced as liquid and flowing, "live" networks in which different unpredictable virtual activities happen: virtual links and connections emerge, vanish, and revive. The use of metaphors in grounded theory methodology facilitates explanation of social processes. The metaphors and their explanations in grounded theory research are presented in Table 1.

\section{Table 1}

The list of constructed grounded theory categories and related metaphors

\begin{tabular}{llll}
\hline \multicolumn{1}{c}{$\begin{array}{c}\text { Category explaining } \\
\text { Metaphor }\end{array}$} & \multicolumn{1}{c}{ Dimensions of category } & Research participants \\
Stroking the net whale & $\begin{array}{l}\text { Exploiting virtual social } \\
\text { spaces for ubiquitous } \\
\text { learning }\end{array}$ & Students \\
& $\begin{array}{l}\text { Exploiting virtual social } \\
\text { spaces for creative activities }\end{array}$ & Teachers \\
Building boats & $\begin{array}{l}\text { Social networking } \\
\text { Adentity marketing }\end{array}$ & Both groups \\
ocean & $\begin{array}{l}\text { Personal capabilities } \\
\text { Mutual trust }\end{array}$ & Both groups \\
& $\begin{array}{l}\text { Enforcing formal studies } \\
\text { Nurturing the big fish }\end{array}$ & Students \\
& Academic communication & Both groups \\
& $\begin{array}{l}\text { Developing virtual learning } \\
\text { skills }\end{array}$ & Students \\
& $\begin{array}{l}\text { Developing } \\
\text { knowledge }\end{array}$ & Teachers \\
\hline & & \\
\hline
\end{tabular}

In the following section, we present the constructed categories that taken together give an understanding of the processes of SRL of teachers and their students taking place in virtual social spaces and summarize its different components. The interview data were codified using a two 
symbols system. The first symbol showed the interview number. The second symbol identified the type of participant: interviews with students were codified with the symbol S, while lecturers and researchers were codified with the symbol A. For example, codification 6A showed that this was evidence from the sixth informant teacher.

\section{Stroking the Net Whale}

Whale is a common name for huge marine creatures. Whales live in an open ocean. They are wild and dangerous if you don't know how to deal with them. Stroking the net whale was constructed as the core category that explained the main actions in our data. This category showed that students exploit the virtual social spaces for ubiquitous learning and their teachers exploit virtual social space for creative activities. Students learned effective information while being connected; treated the online information and texts as equally important for learning as formal class materials; sought more active involvement of their teachers' in common virtual activities; and used networks for solving formal class challenges. Their professors created social network groups and shared materials:

Most of us spend a lot of time on Facebook. We always have smartphones on hand. We receive notifications if someone is uploading. And we quickly find out all the related information (5S)

I hadn't expected that my virtual groups would become the space for the texts and information sharing and students would be so eager to do that. I even didn't appreciate how much time the young people spent in networks. This discovery astonished me. <...> I did my first posts and shares I thought that this group needs me as a teacher because I needed a space for my communication with them. I thought I would write: "let's meet here and there; you need to bring this or that; read this post". I thought the group that I created was for publishing the assignment texts, but as time passed, I realized that students also want to share, not only me posting. They wrote to me: "could I post this for other people in my group?" These were the first steps, the first virtual group where they, my students, also started sharing, following, reading, and becoming interested (6A) 
Teachers used networks for creative activities and explored virtual social spaces for creative group work with their virtual friends:

I re-use the net materials in my formal classes. I use networks searching the ideas for lectures. I search for the pieces that would be possible to apply. I search for some ideas, scientific and popular science papers, hints and references, some other texts. I need only some parts of the materials. There were no situations that I used all the materials without my personal changes and additions. I could say that I adapt some papers for my classes. Sometimes I find "pearls" (1A)

I was invited by a stranger. When I added him to my network, he wrote me a message saying: "hello, maybe we can write common articles. These conferences are planned" $<\ldots>$ this is an example how to exploit the networks. International networks. <...> adding people to your network, you can openly say: "Hi, maybe we could write an article together?" If you want and are brave enough, you can invite virtual friends to create academic outputs. (8A)

University professors valued network data and even used it in personal lectures. Besides that, they respectfully and responsively use the technology:

I do not like intimacy in networks. For me, networks are first of all tools for getting information faster. Networks are sharing channel, but not a place for personal life. (3A)

I think that social networks are very welcome for solving problems that ask for your creativity and contemplations. We need to use networks to search some materials or virtually create $(4 \mathrm{~A})$

The core category - Stroking the net whale - was constructed based on data illustrating how the participants grow in the process of stroking/exploring the net whale. Research participants develop their academic, study and occupational skills with new information and knowledge in academic communication, during virtual learning and professional knowledge development. The process of academic 
communication was the same for both groups, teachers and students. Additionally, students develop virtual learning skills whereas their teachers develop professional knowledge. Involvement of active students and their teachers in networking activities was influenced by social networking and identity marketing and depended on their individual capabilities, enforcement of formal studies and maintenance of virtual identities. The different components of the Stroking the net whale process show why participants made decisions to participate and develop active involvement in SRL and were explained by the categories Building boats, Angling in the multifaceted ocean, and Nurturing the big fish. Different processes or components of the processes were applied to university teachers and their students. Figure 1 illustrates how these categories are linked to each other and to the core category. The arrows indicate the direction of SRL skills development and growth (Fig. 1).

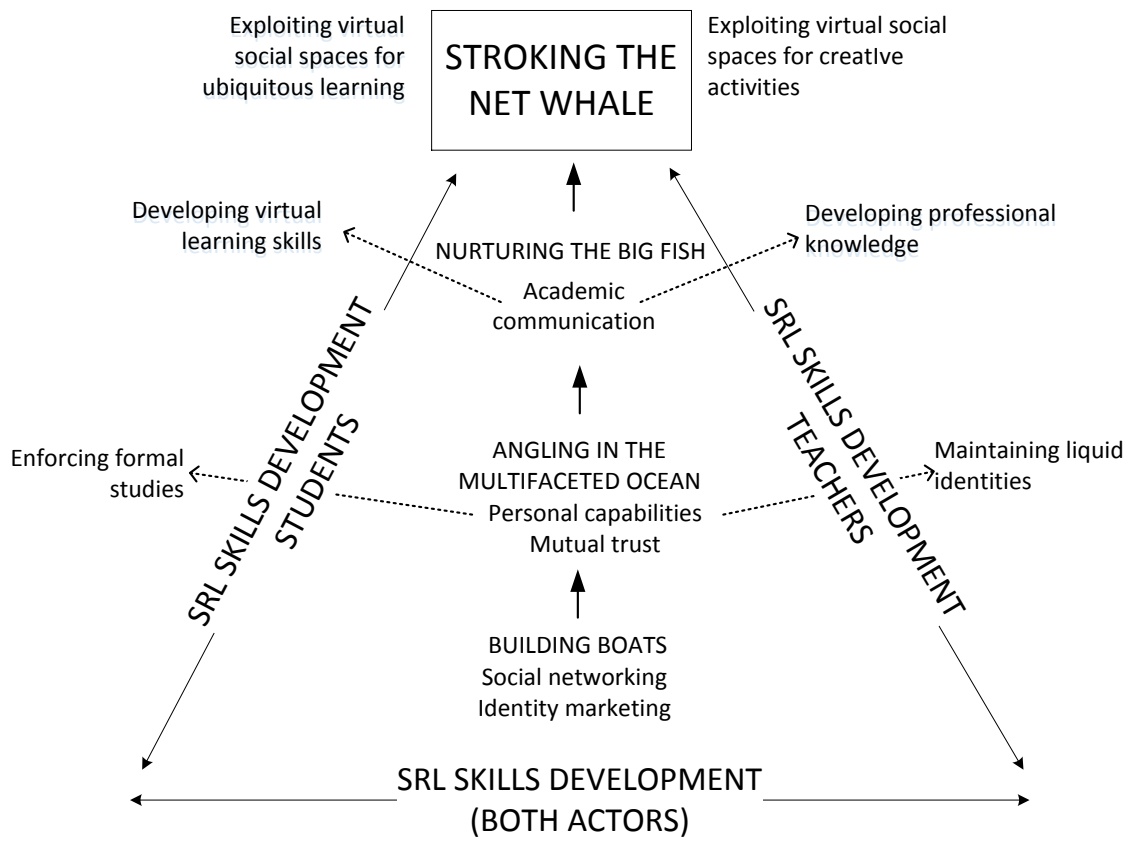

Figure 1. Stroking the net whale: mapping the constructivist grounded theory of SRL in virtual social spaces. 
A whale is an animal that needs to be tamed before putting to work. In virtual social spaces you make friends with other people and start common activities: communication, collaboration, sharing, and crowdsourcing before you begin to exploit the net materials. Findings showed that mastering how to manage the net materials helped both groups of participants to exploit the net for versatile learning and creative activities. The constructed grounded theory described the continuous and neverending process of developing SRL: Building boats precedes Angling in the multifaceted ocean which leads to Stroking the net whale influenced by Nurturing the big fish. Because of its fluid nature, the SRL of university teachers and their students could be suspended, stopped, and revived at any point; and teacher-learner roles can change. University teachers and their students at the same time could learn and teach their virtual friends.

\section{Building Boats}

Building boats is a category metaphorically explaining the processes of preparing self-regulated networked learning. Symbolically speaking, human identity in virtual social spaces could serve like a fishing boat. While in virtual social spaces people construct, present and market their identities (build boats) to catch the audience (big fish). Students are curious about their professors' online profiles. Teachers want to learn about their students' lives to improve communication and even formal lectures:

I connect to my teachers to find out what they are doing, how they live. Once connected, I can contact them quicker. I notice when they see what I wrote on the net. While connected, I have permanent contact with the teacher. It's not the same as just observing people. You can see if he saw your question, the websites he is visiting, what his interests are. By watching them online, I understand more about my teacher's activities (3S)

It's important for me to see my students' living world. If I can monitor my students online, then there's the value of the network. While connected, I can feel the rhythm of students' life. I see what events they are involved in, what they are interested in. It's interesting to me because these things say a lot about students. I see that my students do not "accidentally apply for university". I see 
that some of them are very busy, do things related to studies, improvement and self-learning (12A)

Some virtual friends could tolerate your "boat" (or the online identity you created) with caution. If you chose appropriate casting equipment you would surely catch the desired fish quickly. If you construct your identity with responsibility and actively go for social networking you will find colleagues, friends and congenial people from whom you could learn, get inspiration, or compete.

I observe virtual accounts of all Lithuanian and some foreign universities. I observe their lives, their activities on social networks. I learned from networks how to attract new students to the university. I observe competition authorities. From these observations I get my work inspiration (6A)

Actions and interactions forming the SRL of university teachers and their students consist of social networking and identity marketing. Social networking for teachers consists of searching for online materials and shared virtual texts. Also, keeping virtual contacts with the students is important to them. Through the networks teachers could motivate and encourage students, but they prefer to connect only with group leaders:

I do not have any special content on my account. There is no information such that I cannot publicly display. I connect with one or two students and later they add the rest of the student group. If I do not see a student for a while, I write him a message: "Where are you, why are you not attending my lectures?" (5A)

Social networking for students meant managing and helping in organizing their formal studies, as well as participating in net activities and surfing for the learning materials. Some students themselves create academic content and discuss it with their peers and groupmates:

It's easier to share academic information through the $\mathrm{Fb}$ group. For example, we need to do some work and we do not completely understand the task. So we ask the group: "have you already done this task? Could some of you share how you did it?"(9S) 
I'm looking for others with whom I could talk virtually about an issue that interests me. I am looking for groups to get involved in. I find other people's posts and we talk, we interact. <..> I'm thinking about the content I'm posting. I publish content and wait to see who responds. I always ask myself: "Are there people for whom this content is interesting? Does it affect them?"(12S)

Identity marketing for both participant groups is online self-presentation and open-ended account construction. Students also stressed passive net membership. Some professors virtually consult students and communicate with them treating students as professionals. Other teachers feel the necessity to control students because of lack of their motivation:

You can login to Facebook and you can logout $\langle\ldots\rangle$ but the learning always has some elements of compulsion. <...>Yes, the learning is compulsory. $\langle\ldots\rangle$ a student is born to be forced. I never met a person who says: "I can sit and study that subject myself". All the students face periods of groans and low motivation. <...> if there is a control mechanism, student could easier overcome the difficulties (15A)

Teachers guessed student intentions virtually to befriend them, but not all the teachers expressed the initiative to be connected. Students asked for virtual friendship with their teachers because they hunted for the contacts or wanted to present their academic achievements personally:

Normally students ask to connect because of a willingness to start the common activity. $\langle\ldots\rangle$ they ask for non-formal individual assignment evaluation, remarks and jottings or help accomplishing their formal study-work. They ask for written explanations how to solve the task, why something is not working etc. (19A)

Creating a group would encourage student interest in the subject. If students see their teacher logged in - they would quickly write subject-related questions. The probability of a student overcoming fear of communication with a teacher would increase. The student's interest in the subject would increase $(6 \mathrm{~S})$ 
Social networking and identity marketing mostly comprised conditional actions to initiate SRL.

\section{Angling in the Multifaceted Ocean}

Angling in the multifaceted ocean is a category explaining uncertainties and feelings of insecurity and at the same time new valuable opportunities while being involved in networked SRL. Angling in the ocean is a challenging adventure. The sea is always unpredictable - wind could generate waves, weather changes from sun to rain and fish hide from being caught. Fishermen could use cages, pots, traps, lines, or gillnets to attract and catch sea creatures. With a rod, you could catch fewer fish but you can choose the ones you like. Using a rod while angling in the ocean will not harm the environment. The research findings showed that personal capabilities (how, where and when you catch your fish) is a common property to both actor groups. For academics, personal capabilities mean control over technologies (controlling your fishing rod) with, at the same time, limited use of various social technologies (limited usage of different fishing lines). Net time management was recognized as an important issue by both groups of participants. Besides that, students talked about the inconsistency of various internet technologies, software and devices (lack of boats) as well as instability of individual net activities; liquid activeness influenced by other non-education interests; even mood changes influenced by posts:

Some of the time on the net is pointless... The network "caches" you. You spend more time than necessary. The net sucks you in. The same as the gambling games do $(2 \mathrm{~A})$

Spending time on Facebook is a way of passing time. When I have nothing to do I go to Facebook. I spend fifteen minutes on Facebook, then I go to eat or read a book. After this I'll return to Facebook. When I spend time on Facebook I relax. I smile when I see funny posts (1S)

My mood lifts while I'm following and browsing (7S)

Teachers observed and evaluated the network with all its virtual activities, assessed virtual friends, and verified validity of online texts. 
Teachers observed liquid identities of other net members and sought selfpreservation and a protection of their virtual accounts. Some university teachers reservedly friended students and deliberately chatted (fishing was not their main life activity):

For me, the virtual world is more dangerous than real. I feel myself not secure. <...> If I live-talk - this is not an argument. Even if we chatted I could say we were not. But if something is posted or messaged - everything is fixed. If you wrote something in social networks environment - it would be hard to delete that text. If you have used your voice - this is safer (3A)

You know that term - lurker? That is how I identify myself. I enter, I see what's being posted. I rarely answer the posts. I follow discussions; I observe them. Anything I find interesting I recheck on various sites. But I never contribute. I'm just watching (10A)

Maintenance of liquid identities was observed as an important issue for teachers. Incidents of hacked accounts and stolen information are known and are treated carefully. Teachers discussed net security with colleagues, even thinking about quitting their accounts because of privacy issues:

I suggested using personal security applications. This is necessary for not letting other people observe your account and tag your photos without your permission. If somebody tags you - you definitely need to know that (7A)

My private space is mine alone. Network tells me to open it, but I don't want to $<\ldots>$ I know that twenty or thirty people will see my "button click" and I don't like it (4A)

In building friendships over the network, relationships between coworkers and work-subordination issues were recognized as key factors. Findings showed that personal information from the networks of teachers could be applied and adopted according to the employers' demands; work activities could be observed; conflict situations aroused. Besides that, the university teachers solved professional issues virtually; communicated and 
collaborated, crowdsourced with their peers and scholars from the entire world:

I can hardly find congenial company in real life $\langle\ldots$... those people who could be my ideal professional partners. $<\ldots>$ even in my work environment I couldn't find such creative communication. Though, on LinkedIn I could find that type of communication. On a narrow level, but I accept that (2A)

Mutual trust was a breakwater for university teachers and their students. Students and teachers solve academic and non-academic problems together. Even crowdsourcing was observed:

I had a point to deal with, and other network members helped me a lot. Some of them I don't know in real life, but they have also encountered a similar problem. I talked to people who understand me perfectly because they are or were in a similar situation. I don't know where to find such a group, if not online (1A)

Both research participants' groups were concerned about academic consciousness; respect; disjuncture; recognition. Some students saw not much online confidence in teachers, followed their own preconceptions, and created opinions from the texts they observed and read. Students do not always think before they post. They publicized trash information, shared study materials, results and assignment answers and exam texts, and bullied online:

When I share the posts I never think why I do that $<\ldots>$ it seems to me that we all exchange posts without thinking. We litter and make rubbish everywhere $(12 \mathrm{~S})$

This wonderful tool - the network - is being used for spam. I could sense that. Nobody is responsible and everybody has the power to advertise and publish some kind of nonsense. This is absolutely not the purpose of the network $(2 \mathrm{~A})$

Not all students reacted positively to their teachers' virtual requests. Some students avoided attention themselves, but searched and reviewed 
their teachers' accounts. Some students did not connect with their professors because they felt afraid of future consequences. After communicating with their teachers, students appear to be changed:

Our university professor asked us to create a group. He came to a lecture and said: "We could communicate through Facebook platform". One of the students founded a new virtual group. Invited teacher and other students... From the very beginning it was very unaccountable and funny for me. Our professor is superior so how he could so easy virtually communicate with us? But later I really liked that $(4 \mathrm{~S})$

Enforcement of formal studies for university students was related to study motivation issues. Self-regulated students in social networks made and discussed proposals for learning process acceleration, because they felt responsible for learning (more advanced and less complicated fishing using the same ocean angling techniques).

\section{Nurturing the Big Fish}

Nurturing the big fish is a category describing how academic communication and skills development progress. Sea fish are not pets; only an experienced aqua culturist could take care of them. Research findings showed that university teachers and their students occupy virtual social spaces through academic online communication which leads to virtual learning and academic knowledge development.

Academic communication for students means teacher-inspired socialization; students' contacts with their teachers and peers; private communications; commenting and discussing. Academic communication for their professors and instructors means communication with their colleagues and students; and personal communication on non-work-related issues. Teachers observed and studied the consequences of virtual communication; and evaluated the reliance on virtual communication:

Networks are substitutes for real life. The problem is that live communication skills are declining. A lot of people are addicted to these social networks. For them the first thing on waking up is to check their personal accounts. They check their accounts even 
when sleeping! I saw one person who commented online how many messages he sent. All the time, whatever they do, even while eating, they chat. They cannot be disconnected. All the time they are online. They are connected in a family and in class environment... This is an addiction. They become dependent. (17A)

Virtual learning for self-regulated students means knowing from the new posts as quickly as they arrive; reading popular science texts from their professors' posts; effective finding of required information; selective information sorting; group work and formal study tasks solving initiation in networks; following the scientific news; learning while reading virtual friends wall posts:

How honestly do students share? Enough. As far as I've noticed, if someone asks for an opinion, they get the answer quickly enough $(5 S)$

I had a study assignment - to perform practice in a school. I was told to observe the class work. I needed to find a class to observe teacher-student school activities. I asked for support from the teachers whom I had in my virtual friends' list. I wrote them a private message asking to visit their educational activities in class. I wanted to sit physically in a class and to observe the work. They agreed to let me in, they didn't object. <..> and, I remember I needed something for my studies. I sent an electronic form, and they completed it and sent me their answers (9S)

Academic knowledge development for professors and lecturers means continuously learning; development of skills; gaining professional information; testing the new technologies and investigating; contemplating the application of net tools:

I think that for every subject of educational work - it doesn't matter that exactly we do or develop we need to find proper tools. Using tools that are specially created for this specific purpose will achieve the best results. To tell the truth, if I compare it with other systems, formal learning using Facebook would be a challenge to me. This system is complicated because it doesn't have tools for evaluation and convenient learning material posting <...> it is complicated to 
write feedback on the uploaded materials. If you want to stress that students upload materials before the specified deadline, if you want to see how students upload - Facebook is not an educational tool for you (9A)

Both groups of participants treat their network contacts as an opportunity to Nurture the big fish which they need to breed for the academic communication, virtual learning and academic knowledge development issues. Sea fish are sensitive creatures. Only your personal efforts, motivation communicate and collaborate could build the result of self-regulated networked learning.

\section{Discussion}

This study focuses on processes of networked SRL and draws parallels with the human actions of sea fishing. University teachers' and their students' SRL in virtual social spaces were described as a process metaphorically called Stroking the net whale. Participants' learning followed different paths: university students exploit virtual social spaces for ubiquitous learning and their teachers exploit networks for creative activities. The study showed that contrary to traditional curricula based on long-accepted knowledge, research participants themselves created and developed networked knowledge circuits. Networked SRL is not easily compared with any formal teaching-learning structures. Construction of multiple meanings researched by Romero and Lambropoulos (2011) as a construct of SRL was found in different means of net exploration.

Social media has the potential to bridge formal and informal learning through participatory digital cultures (Greenhow \& Lewin, 2016). Our research showed that only students exploit virtual social spaces for ubiquitous learning. Greenhow and Lewin (2016) described two different perspectives on young people's social media use, and in both cases elements of self-determination in learning purpose and self-direction of learning process was established. For our research participants, selfdirection of learning was also expressed, but some learners (both teachers and students) lacked motivation and final learning targets. They "touched" the learning and were not immersed in the depths of the process. 
The Building boats category metaphorically explained university teachers' and their students' networked SRL initial processes (virtual identity marketing and willingness to test social networking activities). Dunne, Lawlor and Rowley (2010) explored young people's participation in social networks from a uses and gratifications perspective, finding the main gratifications as communication, entertainment and friending. Our findings enlarged these results adding the new gratification: identity marketing. In our study, the entertainment part was not pursued. Dynamics of knowledge development and transfer in teams as described in Seddon (1988) and later researched in virtual environments by Griffith et al. (2003) was observed for both groups of participants.

The Angling in the multifaceted ocean category explained university teachers' and their students' SRL in virtual social spaces stressing that how you create and re-construct your identity influences from and with whom you learn. Findings indicated that personal capabilities and mutual trust changed the way how participants build their virtual relationships. This is in line with Ellis' (2016) research on creative learning principles, which found that learning is acquired through the creative process of problem solving when persons trust their peers. Creative solutions are attributed to previously known, recalled, applied, practiced and re-created person's knowledge and this work only in safe environment build on peer-trust. In virtual social spaces where teachers and their students make virtual friendships and communicate they continuously adjust their digital identities collaboratively constructing new knowledge.

Mutual trust is the main building block for virtual communities and crowdsourcing platforms (Agreste, De Meo, Ferrara, Piccolo, \& Provetti, 2015). Research participants (teachers and students) did not express concern for the well-being, learning process and outcomes of their fellows, but concentrated on personal capability growth. This feature was especially manifest in teachers. To prove this, teachers gave examples of some of them not adding their students to personal networks so as "not hamper their professional growth". This resulted in Angling in the multifaceted ocean, meaning in many cases finding learning solutions alone or without the help of the crowd.

The Nurturing the big fish category we constructed out of virtual student-teacher communication in non-formal and informal environments, virtual learning and professional knowledge development. Our study 
revealed academic communication as one of the most challenging processes of SRL in virtual social spaces. University students and their professors are challenged by virtual peer and group communication in non-academic environments. These findings broadened Crosnoe et al. (2004) research about the connection between student-teacher relationships and intergenerational bonds to learning results and partly contradicts Pianta et al. (2012) research on students' engagement direct dependence upon academic support.

\section{Conclusions, Study Limitations and Future Research}

The constructed grounded theory Stroking the net whale explained the SRL processes of two academic agencies - university professors and instructors and their students - in virtual social spaces. Stroking the net whale comprised three categories: Building boats, Angling in the multifaceted ocean and Nurturing the big fish. Building boats referred to social networking and identity marketing in virtual social spaces. Angling in the multifaceted ocean had two dimensions that were common to both academic agencies - personal capabilities and mutual trust. While Angling in the multifaceted ocean, teachers maintain their liquid identities and students reinforce their formal university learning. Nurturing the big fish showed different components of the SRL process development - both actor groups learn the building of academic communication, while in addition students develop virtual learning skills, and university teachers develop professional knowledge.

Combination of originality and credibility increased resonance, usefulness, and the subsequent value of the constructed grounded theory (Charmaz, 2006). The research credibility was developed through systematic comparisons between interview data, memos, codes and categories. As research participants, university teachers were asked to recommend their students for new interviews to cover a wider range of observations. Text, visual and audio memos helped not to be lost in data, gathered new arguments, and helped to compare categories with categories. Visual memos, describing research participant experiences, were discussed with participants seeking to understand whether the graphical explanation made sense to academic parties. These sessions specified data and offered deeper insights about SRL. 
Research participants were Lithuanian university teachers and their students. Findings showed that our participants were virtually connected not only with local and national parties. The selection of research participants from only one country was perceived as study limitation. On the other hand, such a pool of participants allowed understanding and inclusion of cultural issues such as student-teacher peer communication in virtual social spaces. Data grounded in voices of international academics and non-academics, related with academic parties, can benefit the findings.

\section{References}

Agreste, S., De Meo, P., Ferrara, E., Piccolo, S., \& Provetti, A. (2015).

Trust Networks: Topology, Dynamics, and Measurements. IEEE Internet Computing, 19(6), 26-35. doi:10.1109/MIC.2015.93 Bauman, Z. (2005). Education in liquid modernity. The Review of Education, Pedagogy, and Cultural Studies, 27(4), 303-317. doi:10.1080/10714410500338873

Bauman, Z. (2013). Liquid modernity. New York: John Wiley \& Sons. Birks, M., Chapman, Y., \& Francis, K. (2008). Memoing in qualitative research: probing data and processes. Journal of Research in Nursing, 13(1), 68-75. doi:10.1177/1744987107081254

Braidotti, R. (2013). Posthuman humanities. European Educational Research Journal, 12(1), 1-19. doi:10.2304/eerj.2013.12.1.1 Castells, M. (2013). Communication power. Oxford: Oxford University Press.

Charmaz, K. (2006). Constructing grounded theory: A practical guide through qualitative research. London: Sage Publications Ltd.

Charmaz, K. (2008). Constructionism and the grounded theory method. In A. Bryant \& K. Charmaz (Eds.), The Sage handbook of constructionist research (pp. 397-412). Thousand Oaks, CA: Sage.

Charmaz, K. (2011). Grounded Theory Methods in Social Justice Research.

In N.K. Denzin \& Y. Lincoln (Eds.), Handbook of qualitative research (pp. 359-380). Thousand Oaks, CA: Sage.

Clarke, A. (2005). Situational analysis: Grounded theory after the postmodern turn. Thousand Oaks, CA: Sage.

Crosnoe, R., Johnson, M. K., \& Elder, G. H. (2004). Intergenerational bonding in school: The behavioral and contextual correlates of 
student-teacher relationships. Sociology of Education, 77(1), 60-81. doi:10.1177/003804070407700103

Csikszentmihalyi, M., \& Wolfe, R. (2014). New conceptions and research approaches to creativity: Implications of a systems perspective for creativity in education. In M. Csikszentmihalyi (Ed.), The systems model of creativity (pp. 161-184). Dordrecht: Springer Science+Business Media.

Dunne, Á, Lawlor, M. A., \& Rowley, J. (2010). Young people's use of online social networking sites-a uses and gratifications perspective. Journal of Research in Interactive Marketing, 4(1), 4658. doi:10.1108/17505931011033551

Eisenbeiss, M., Blechschmidt, B., Backhaus, K., \& Freund, P. A. (2012).

"The (real) world is not enough:" motivational drivers and user behavior in virtual worlds. Journal of Interactive Marketing, 26(1), 4-20. doi:10.1016/j.intmar.201106.002

Ellis, V. A. (2016). Introducing the Creative Learning Principles:

Instructional Tasks Used to Promote Rhizomatic Learning through Creativity. The Clearing House: A Journal of Educational Strategies, Issues and Ideas, 89(4-5), 125-134.

doi:10.1080/00098655.2016.1170448

General Assembly of the World Medical Association (2014). World Medical Association Declaration of Helsinki: ethical principles for medical research involving human subjects. The Journal of the American College of Dentists, 81(3), 14-18.

Greenhow, C., \& Lewin, C. (2016). Social media and education: reconceptualizing the boundaries of formal and informal learning. Learning, Media and Technology, 41(1), 6-30. doi:10.1080/17439884.2015.1064954

Griffith, T. L., Sawyer, J. E., \& Neale, M. A. (2003). Virtualness and knowledge in teams: Managing the love triangle of organizations, individuals, and information technology. MIS Quarterly, 27(2), 265287. Retrieved from https://www.jstor.org/stable/30036531?seq=1\#page_scan_tab_conten ts

Holton, J. A. (2007). The coding process and its challenges. In A. Bryant, \& K. Charmaz (Eds.), The Sage handbook of grounded theory. (pp. 265-289). Thousand Oaks, CA: Sage. 
Karabenick, S. A., \& Zusho, A. (2015). Examining approaches to research on self-regulated learning: conceptual and methodological considerations. Metacognition and Learning, 10(1), 151-163. doi:10.1007/s 11409-015-9137-3

Kvale, S. (2008). Doing interviews. Los Angeles: Sage Publications. Littlejohn, A., Hood, N., Milligan, C., \& Mustain, P. (2016). Learning in MOOCs: Motivations and self-regulated learning in MOOCs. The Internet and Higher Education, 29(1), 40-48. doi:10.1016/j.iheduc.2015.12.003

Pianta, R. C., Hamre, B. K., \& Allen, J. P. (2012). Teacher-student relationships and engagement: Conceptualizing, measuring, and improving the capacity of classroom interactions. In S.L.

Christenson, A. L. Reschly \& C. Wylie (Eds.), Handbook of research on student engagement (pp. 365-386). Berlin: Springer.

Pintrich, P. R. (2000). The role of goal orientation in self-regulated learning. In M. Boekarts, P. R. Pintrich \& M. Zeidner (Eds.), Handbook of self-regulation (pp. 452-502). San Diego, Calif.: Academic Press.

Romero, M., \& Lambropoulos, N. (2011). Internal and external regulation to support knowledge construction and convergence in computer supported collaborative learning (CSCL). Electronic Journal of Research in Educational Psychology, 9(1), 309-330. Retrieved from http://www.investigacion-

psicopedagogica.org/revista/new/english/ContadorArticulo.php?513

Schultze, U. (2014). Performing embodied identity in virtual worlds. European Journal of Information Systems, 23(1), 84-95. doi:10.1057/ejis.2012.52

Schunk, D. H., \& Zimmerman, B. J. (Eds.). (2012). Motivation and selfregulated learning: Theory, research, and applications. London: Routledge.

Seddon, T. L. (1988). The transition in New South Wales schooling: From federation to Keynesian settlement. Education Research and Perspectives, 15(1), 60-69.

Solomon, M. R. (2014). Consumer behavior: Buying, having, and being. Englewood Cliffs, NJ: Prentice Hall.

Varnelis, K. (2012). Networked publics. Cambridge, Massachusets: The MIT Press. 
Vivian, R., Barnes, A., Geer, R., \& Wood, D. (2014). The academic journey of university students on Facebook: an analysis of informal academic-related activity over a semester. Research in Learning Technology, 22(1), 1-17.doi:10.3402/rlt.v22.24681

Judita Kasperiuniene is a Lecturer at Faculty of Informatics at Vytautas Magnus University and Centre for Cultural Communication and Education at Aleksandras Stulginskis University, Lituania. ORCID, id: 0000-00016851-7637

Vilma Zydziunaite is a Professor in Education, Social Sciences at Vytautas Magnus University, Lituania

Malin Eriksson is an Associate Professor Department of Social Work at Umeå University, Sweden. ORCID, id: 0000-0003-0108-4237

Contact Address: Judita Kasperiuniene, Faculty of Informatics, Vytautas Magnus University, Vileikos g. 8-409, Kaunas 44404, Lituania. Email: judita.kasperiuniene@gmail.com 